\title{
30. EARLY DIAGENESIS IN AMAZON FAN SEDIMENTS ${ }^{1}$
}

\author{
Stephen J. Burns ${ }^{2}$
}

\begin{abstract}
Early diagenesis in sediments of the Amazon Fan is strongly influenced by the high iron content of the pre-Holocene fan sediments. The diagenetic mineral assemblage is composed almost exclusively of iron-bearing phases: iron sulfides (hydrotroilite and greigite), vivianite $\left(\mathrm{FePO}_{4} \cdot 8 \mathrm{H}_{2} \mathrm{O}\right)$, and siderite $\left(\mathrm{FeCO}_{3}\right)$. Iron sulfides form in the zone of sulfate reduction. Millimeter-sized vivianite nodules are common and begin to form as shallow as 0.5 meters below seafloor (mbsf), and continue to form to $\sim 20 \mathrm{mbsf}$. Siderite is also common, forming as dispersed 1- to 5- $\mu \mathrm{m}$ crystals from the upper few mbsf to $\sim 20 \mathrm{mbsf}$.

Numerical modeling of sulfate reduction and ammonium production demonstrates that the modern pore-water profiles are not in a steady state, but have been migrating through the sediments in response to $\sim 100 \times$ decrease in sedimentation rates at 9.5 $\mathrm{ka}$. Calculated initial rates of sulfate reduction and ammonium formation range from 1.7 to $6.0 \times 10^{-13} \mathrm{moles} / \mathrm{liter} / \mathrm{second}(\mathrm{M} / \mathrm{s})$ and 2.5 to $5.0 \times 10^{-14}$, respectively. The pre-Holocene depths to sulfate depletion were on the order of $20-50 \mathrm{mbsf}$, rather than the 5-10 mbsf presently observed. The zones of diagenetic mineral formation were thus considerably deeper than indicated by present pore-water chemistry.
\end{abstract}

\section{INTRODUCTION}

The remineralization of organic matter in marine sediments is probably the most studied aspect of sediment diagenesis. Organic carbon burial and preservation in different marine environments have obvious application to hydrocarbon exploration. By controlling the redox chemistry of pore waters, organic carbon diagenesis also affects the overall diagenetic environment. Early diagenesis and organic matter remineralization in the oceans are often considered to occur in two end-member environments: the deep sea, where little metabolizable organic matter reaches the seafloor and the effects of diagenesis are small, and near-shore environments, where significant organic material is buried with the sediments and the effects of early organic matter diagenesis are large.

The Amazon Fan, however, is an anomalous deep-sea environment in which significant amounts of organic matter reach the deep sea. Furthermore, much of the organic material deposited is of terrestrial rather than marine origin. The processes and rates of early diagenesis in such environments are relatively unstudied in comparison with either near-shore sediments or true pelagic sediments. The objectives of this paper are to investigate the processes, products, and rates of early diagenesis of the Amazon Fan.

\section{Geologic Setting}

The Amazon Fan is built primarily of terrigenous sediment derived from the Amazon Basin and carried out to sea by the Amazon River. The behavior of this system, however, is greatly dependent on sea level. During sea-level lowstands, the Amazon River crossed the continental shelf and delivered its sediment load directly to the Amazon Canyon and the deep sea (Damuth and Fairbridge, 1970; Damuth and Kumar, 1975). The tremendous volume of sediments reaching the deep sea resulted in very high sedimentation rates, on the order of several meters to more than $10 \mathrm{~m} / 1000 \mathrm{yr}$ (Flood, Piper, Klaus, et al., 1995). In contrast, during sea-level highstands, such as at present, Amazon River-borne sediments are deposited on the conti-

${ }^{1}$ Flood, R.D., Piper, D.J.W., Klaus, A., and Peterson, L.C. (Eds.), 1997. Proc. ODP, Sci. Results, 155: College Station, TX (Ocean Drilling Program).

${ }^{2}$ Geologisches Institut, Universität Bern, Baltzerstrasse 1, CH-3012 Bern, Switzerland.burns@geo.unibe.ch nental shelf, building a shelf delta (Nittrouer et al., 1986). The Amazon Fan, deprived of terrigenous input, is the site of pelagic to hemipelagic sedimentation, with sedimentation rates for approximately the last $10 \mathrm{ka}$ of several centimeters per thousand years (Damuth, 1977; Flood, Piper, Klaus, et al., 1995).

Detailed descriptions of sedimentary facies and the modes of deposition of sediments deposited on the Amazon Fan may be found elsewhere (e.g., Damuth and Kumar, 1975; Damuth, 1977; Damuth and Flood, 1984; Flood, Piper, Klaus, et al., 1995). With respect to sediment diagenesis, it is worth noting that a variety of fan environments and sediment types were sampled during drilling during Leg 155 (Flood, Piper, Klaus, et al., 1995), including sand-rich channel facies, mud-rich levee facies, and debris-flow units from both the upper to lower fan. In spite of this variation in a depositional setting, the sediments' organic carbon contents, chemistries, and mineralogies show relatively little variation from site to site. In particular, organic carbon contents are consistently between 0.8 and $1 \mathrm{wt} \%$ (Flood, Piper, Klaus, et al., 1995), with an almost entirely terrestrial source (Goñi, this volume), and total nitrogen contents are generally between 0.08 and 0.1 wt\% (Flood, Piper, Klaus, et al., 1995). Major element compositions of the sediments are also consistent from site to site and show high iron contents of 7 to $8.5 \mathrm{wt} \% \mathrm{Fe}$ as $\mathrm{Fe}_{2} \mathrm{O}_{3}$ (Flood, Piper, Klaus, et al., 1995).

As mentioned above, the character of Amazon Fan sediments changes abruptly near the Holocene/Pleistocene boundary. The uppermost 30 to $70 \mathrm{~cm}$ of sediments are brown to tan pelagic calcareous ooze, at the base of which is a diagenetic iron-rich crust that can be correlated throughout the fan (Damuth, 1977; Flood, Piper, Klaus, et al., 1995). The crust formed as a response to the decrease in sedimentation rate and the subsequent upward migration of reduced iron into the oxic zone of the sediments. The exact age of the change in sediment type and rate of deposition probably varies somewhat across the fan. The iron-rich crust has been dated at $9.3 \mathrm{ka}$ (Showers and Bevis, 1988) on the Amazon Fan, but varies between 8 and 15 ka across the Guiana Basin (Damuth, 1977).

\section{METHODS}

The methods for pore-water analyses are recorded in Flood, Piper, Klaus, et al. (1995). Pore-water iron and manganese concentrations 
must be viewed with some caution, as there are no facilities on the JOIDES Resolution for maintaining anoxic conditions during porewater extraction. It is possible that the oxidation of iron sulfides and/ or precipitation of dissolved iron and manganese into oxide phases took place during pore-water sampling. For that reason, pore-water iron and manganese results are not utilized here in discussing diagenesis, although diagenetic iron minerals are common (Flood, Piper, Klaus, et al., 1995).

The mineralogy of a number of sediment samples was determined by standard X-ray diffraction techniques. Sediments analyzed included those suspected of containing concentrations of siderite and a suite of samples from Site 944 that contained visible iron sulfide-stained areas.

Six samples of sediment containing siderite and six vivianite nodules were coated with osmium and studied using a JEOL scanning electron microscope (SEM). Separate splits of these samples were coated with aluminum and studied under the SEM using an energy dispersive X-ray analytical system (EDS) to qualitatively assess the elemental chemistry of the minerals.

Carbon and oxygen stable isotope ratios were measured for 14 samples of siderite. Approximately $50 \mathrm{mg}$ of sample was reacted in $100 \% \mathrm{H}_{3} \mathrm{PO}_{4}$ at $75^{\circ} \mathrm{C}$ for $72 \mathrm{hr}$ in an off-line reaction system. The resulting $\mathrm{CO}_{2}$ was collected, and the stable isotope ratios were measured on a VG Prism ratio mass spectrometer. The oxygen isotopic ratios were corrected for phosphoric acid- $\mathrm{CO}_{2}$ fractionation using the equation of Carothers et al. (1988). Reproducibility of standard materials is $0.1 \%$ o for oxygen and $0.04 \%$ o for carbon. All results are reported relative to the PDB standard.

\section{SUMMARY OF SHIPBOARD PORE-WATER ANALYSES}

Results of pore-water chemical analyses of all 17 Leg 155 sites are reported in Flood, Piper, Klaus, et al. (1995). The analyses show a quite uniform diagenetic environment with respect to position on the fan. The downcore changes in pore-water chemistry are best seen in the three sites, 931, 939, and 944 (Fig. 1), in which relatively closely spaced $(1.5-3 \mathrm{~m})$ samples were taken from the upper 35 to 40 meters below seafloor (mbsf; Flood, Piper, Klaus, et al., 1995). For example, at Site 944 (Fig. 2), the sediments are anoxic by the shallowest sample at $0.50 \mathrm{mbsf}$, where the sulfate concentration is 20.2 $\mathrm{mM}$, well below seawater values. Sulfate reduction is complete at $\sim 4$ mbsf. Pore-water alkalinity increases through the sulfate reduction zone, to $\sim 22 \mathrm{mM}$, then decreases to $\sim 8$ or $9 \mathrm{mM}$ by $10 \mathrm{mbsf}$. Ammonium values rise steadily over the upper $20 \mathrm{mbsf}$, to $\sim 8 \mathrm{mM}$. Calcium and magnesium concentrations decrease in the upper $8-10 \mathrm{mbsf}$ from seawater values to concentrations of $\sim 4.5$ and $42 \mathrm{mM}$, respectively. Phosphate concentrations increase rapidly from a few tens of micrometers near the surface to almost $400 \mu \mathrm{M}$ at $\sim 5 \mathrm{mbsf}$, then decrease to generally below $10 \mu \mathrm{M}$ by $10 \mathrm{mbsf}$.

Between 10 and 377 mbsf at Site 944, the concentrations of most major dissolved species are nearly constant (Fig. 2; Shipboard Scientific Party, 1995). Only ammonium concentrations continue to change, increasing slowly over the upper $40-50 \mathrm{mbsf}$.

Pore-water results from other sites on the Amazon Fan are very similar to those from Site 944 (Flood, Piper, Klaus, et al., 1995). The major difference from site to site is that the depth to total sulfate depletion varies somewhat. At Sites 931 and 939, sulfate concentrations are 0 by $\sim 6$ and 9 mbsf, respectively. For other sites, there was generally only one pore-water sample within the zone of sulfate reduction, making it difficult to accurately locate the point at which sulfate is totally depleted. At most sites, however, sulfate is removed somewhere above $10 \mathrm{mbsf}$, with the exception of Site 940, where the depth is $\sim 20 \mathrm{mbsf}$. There are also slight differences from site to site in the

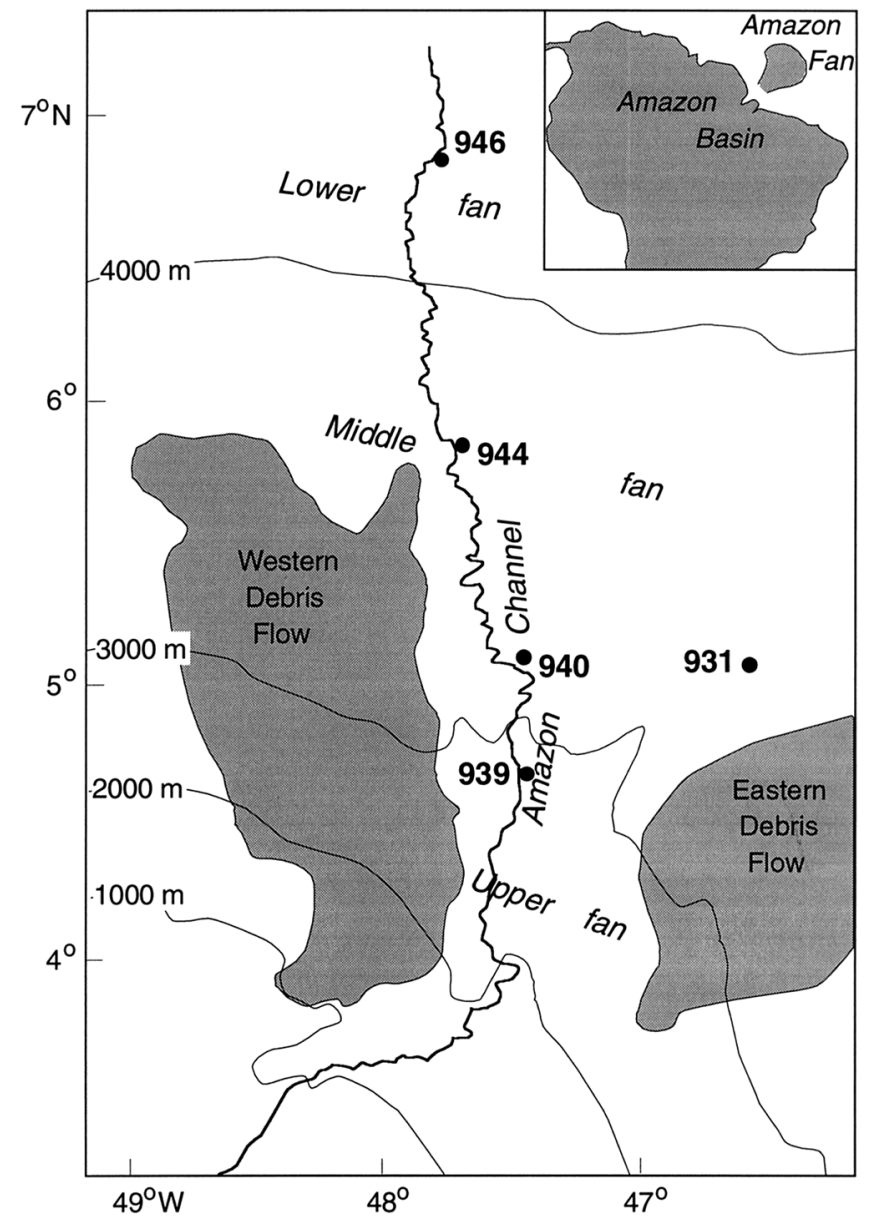

Figure 1. Generalized map of the Amazon Fan showing the location of sites discussed in relation to the Amazon Channel system. Modified from Damuth et al. (1988) and Manley and Flood (1988).

peak concentrations of alkalinity, ammonium, and phosphate, although the relatively widely spaced sampling interval makes it likely that pore waters with maximum concentrations were not sampled. The relative positions of the pore-water profiles of other species, with respect to the sulfate profile, are very much the same from site to site. The peak concentration of alkalinity and phosphate, in particular, coincide with the base of the sulfate reduction zone. Also, most of the observed decreases in calcium and magnesium occur within or just below the sulfate reduction zone. As at Site 944, the pore-water concentrations of all dissolved species change little from 20 to over 400 mbsf.

\section{Diagenetic Reactions and Mineral Formation}

The changes in pore-water concentrations with depth can be interpreted in terms of various reactions involving organic carbon remineralization and diagenetic mineral formation. A sequence of bacterially mediated organic carbon remineralization reactions has been identified for marine sediments (Berner, 1974; Froelich et al., 1979). In general, the sequence of terminal electron acceptors for organic matter oxidation proceeds from the reduction of oxygen to nitrate, Mn oxides, iron oxides, sulfate, and dissolved carbon dioxide, although these reactions do not occur exclusively in discrete depth zones within the sediments (Froelich et al., 1979). The products of these reactions-manganese, iron, sulfide, and methane, along with 

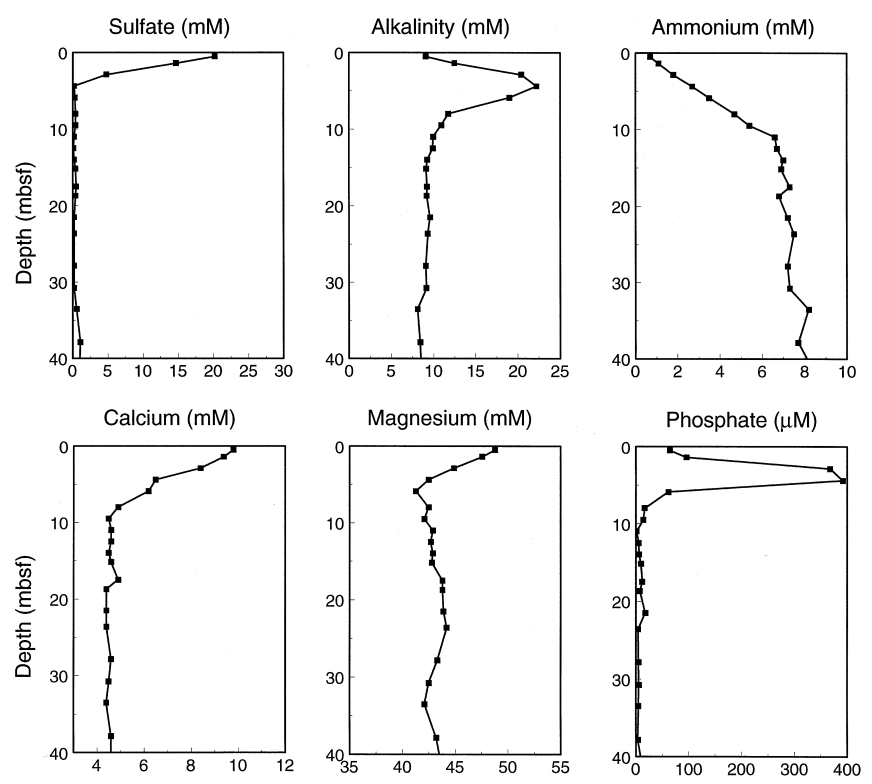

Figure 2. Pore-water chemistry of the upper $40 \mathrm{mbsf}$ for Hole 944D.

ammonium, phosphate, and dissolved $\mathrm{CO}_{2}$-are released to the pore waters and are available for authigenic mineral formation. The porewater sampling intervals on Leg 155 were not sufficient to resolve most of the organic matter remineralization reactions. As mentioned, pore-water sulfate concentrations are below seawater values in even the shallowest samples, from 0.2 to $0.5 \mathrm{mbsf}$. The diagenetic environments can be subdivided only as within and below the zone of sulfate reduction.

In some cases, the mineral products of early diagenesis, and therefore the sedimentary sink for some dissolved species, were readily visible and identifiable in the sediments, but in others, they were not. The first indications of diagenetic mineral formation are irregular patches and layers of sediments stained black with iron sulfides. The first appearance of iron sulfide is generally just below the Holocene, calcareous ooze layer, but within the uppermost meter of the sediments. X-ray diffraction analyses of the iron sulfides from Site 944 and in other work on Amazon Fan sediments (Ericson et al., 1961; Flood and Green, this volume) show that the initial mineral formed is hydrotroilite $\left(\mathrm{FeS} \cdot \mathrm{nH}_{2} \mathrm{O}\right)$. Hydrotroilite was the only iron sulfide found to $23 \mathrm{mbsf}$ at Site 944 . Greigite $\left(\mathrm{Fe}_{3} \mathrm{~S}_{4}\right)$ was also present below 32 mbsf. Pyrite was not found. Except for the absence of greigite near the surface, there was no clear depth-related control on whether greigite or hydrotroilite were present or absent. Either or both were found in the iron sulfides from below $32 \mathrm{mbsf}$. It is therefore not clear whether greigite replaces hydrotroilite, or whether formation of one or the other is controlled by a depositional parameter such as sedimentation rate.

One of the unusual features of the glacial-age Amazon Fan sediments is that they are rich in iron oxides, with concentrations typically between 7 and 8 wt\% iron as oxides (Flood, Piper, Klaus, et al., 1995). In most marine systems, iron put into the pore waters by iron oxide reduction will entirely be precipitated as iron sulfides. On the Amazon Fan, however, sufficient reduced iron is available such that two other diagenetic iron minerals form in significant amounts; vivianite $\left(\mathrm{FePO}_{4} \cdot 8 \mathrm{H}_{2} \mathrm{O}\right)$ and siderite $\left(\mathrm{FeCO}_{3}\right)$.

Vivianite was commonly observed in fan sediments in the form of small nodules, 1-5 mm in size (Flood, Piper, Klaus, et al., 1995). The shallowest occurrence of vivianite nodules in core-catcher samples sieved for microfossil analysis is $2.75 \mathrm{mbsf}$ in Hole 940A. In general,
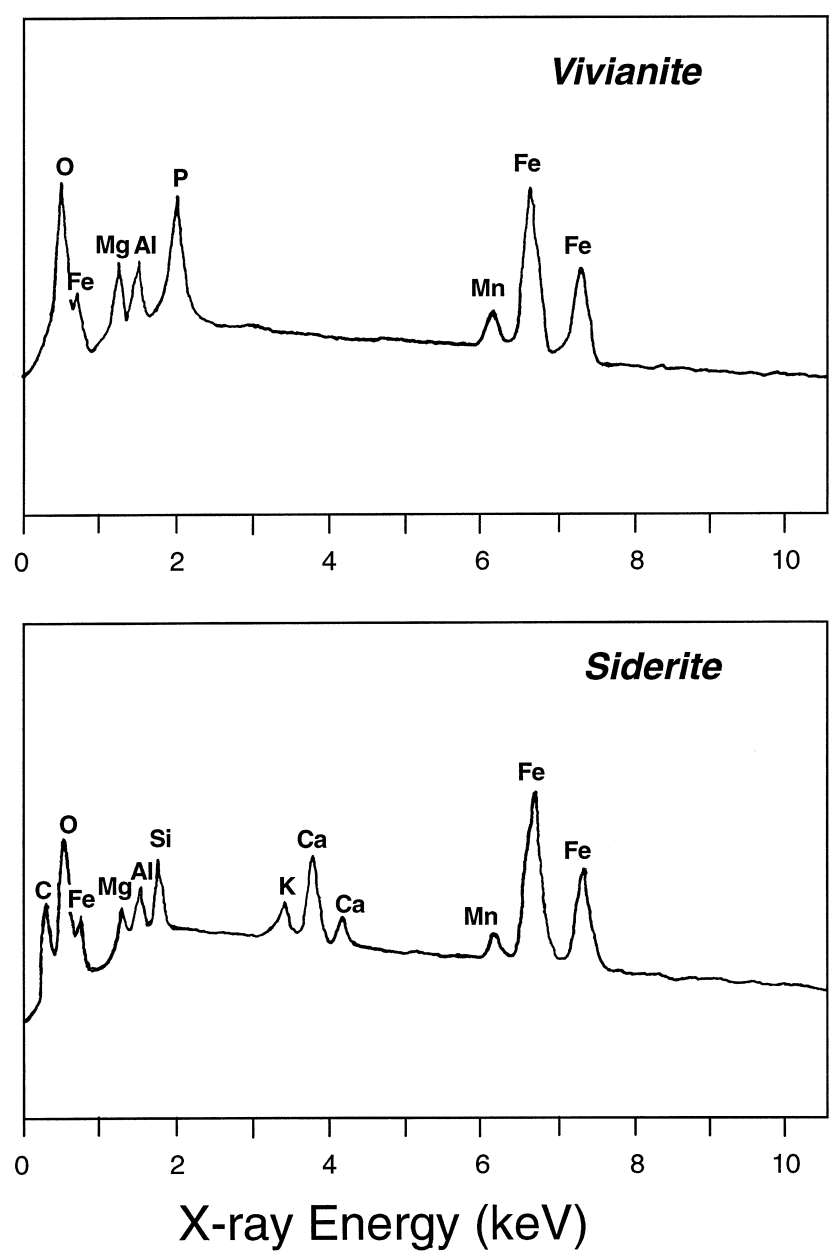

Figure 3. EDS patterns for vivianite (Sample 155-932A-5H-CC) and siderite (Sample 155-938A-17X-2, 81-87 cm). Y-axis is a logarithmic scale of total counts.

vivianite nodules first occur at $\sim 10 \mathrm{mbsf}$, although the first occurrence can be as deep as 50-60 mbsf, such as at Sites 930 and 942. At only Site 940 do visible vivianite nodules occur within the present zone of sulfate reduction. In all other sites, the first macroscopic vivianite nodules were found below the depth of total sulfate depletion (Flood, Piper, Klaus, et al., 1995).

Pore-water phosphate analyses suggest that vivianite forms primarily in the 5-10 m below the zone of sulfate reduction. Phosphate concentrations at all sites increase through the zone of sulfate reduction, reaching a maximum of typically $100-400 \mu \mathrm{M}$ just at the base of the sulfate reduction zone (Fig. 2; Flood, Piper, Klaus, et al., 1995). Thereafter, phosphate concentrations decrease rapidly over the next 5-10 m, to several tens of micrometers. Because the only identifiable sink for phosphate is vivianite, the rapid decrease in porewater concentration is presumably in response to vivianite precipitation.

EDS analyses of the vivianite nodules also provide information on where vivianite forms. The analyses show that the vivianite nodules contain considerable amounts of magnesium (Fig. 3). Although EDS analyses of siderite show that it also contains some magnesium (Fig. 3 ), the major sink for magnesium in the sediment appears to be vivianite. The zone of the sediments where magnesium concentrations decrease thus identifies the zone of vivianite formation. At all sites, 


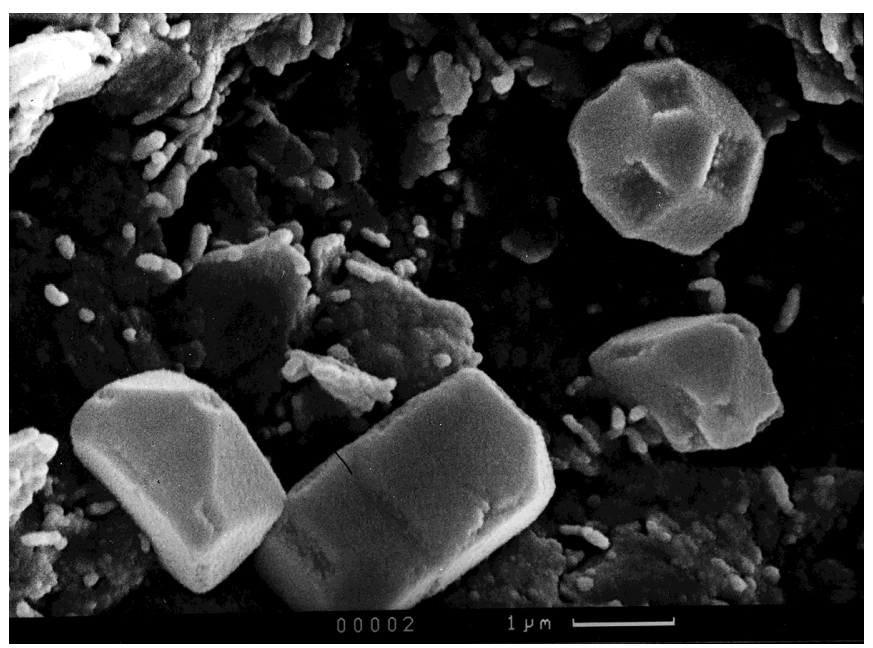

Figure 4. SEM photomicrograph of siderite crystals from Sample 155-938A$17 \mathrm{X}-2,81-87 \mathrm{~cm}$.

pore-water magnesium concentrations begin to decrease very near the surface and continue to decrease to a depth of approximately twice the thickness of the zone of sulfate reduction, or $\sim 10-20 \mathrm{mbsf}$. The magnesium concentrations, therefore, suggest that vivianite forms within this zone.

The third diagenetic iron mineral, siderite, was not as readily observed as iron sulfides or vivianite. Siderite rarely occurred as discrete nodules or layers. Several lines of evidence, however, suggest that small amounts of siderite occur dispersed through the sediments. First, routine shipboard X-ray diffraction analyses of the sediments commonly identified siderite as a minor component of the sediments. Second, measured carbonate contents of the sediments are consistently between 2 and $3 \mathrm{wt} \%$ (calculated as $\mathrm{CaCO}_{3}$ ). Given the relative scarcity of foraminifers and calcareous nannoplankton (Flood, Piper, Klaus, et al., 1995), it is likely that much of this carbonate is actually diagenetic siderite. Third, some sink for pore-water alkalinity is required. Sulfate reduction in marine sediments generally produces approximately 2 moles of alkalinity for 1 mole of sulfate reduced (Berner, 1980, and references therein). Total sulfate reduction should, therefore, yield a concentration of $50-60 \mathrm{mM}$ of alkalinity. Yet, the maximum pore-water values are only $\sim 25$ to $30 \mathrm{mM}$, at the base of the sulfate reduction zone, and values decrease to $\sim 10 \mathrm{mM}$ below the sulfate reduction zone (Fig. 2). No carbonate mineral other than siderite has been found in the sediments. Finally, SEM analyses of the sediments show that siderite occurs as small, individual 1- to 5- $\mu \mathrm{m}$ rhombs (Fig. 4), suggesting that in fan sediments siderite precipitates as finely disseminated crystals rather than as nodules.

Both pore-water analyses coupled with EDS analyses of siderite, and stable isotope ratios of siderite demonstrate that siderite formation takes place primarily in the upper $20 \mathrm{mbsf}$. EDS analyses of siderites indicate that they contain considerable amounts of calcium (Fig. 3). Because no other calcium-bearing diagenetic mineral has been found, siderite is likely the only diagenetic sink for calcium. In response to siderite precipitation, the pore-water calcium concentrations decrease steadily over the upper few tens of meters (Fig. 2). This area probably delimits the area over which most siderite precipitation takes place. As mentioned, siderite is also likely the major sink for alkalinity in the sediments. The point at which pore-water alkalinity stops decreasing coincides with the point at which calcium stops decreasing.

Siderite stable isotopes also demonstrate that siderite precipitation takes place primarily in the upper few tens of mbsf. The carbon isotope ratios of the siderites range from $+2.3 \%$ o to $-22.4 \%$ (Fig. 5).

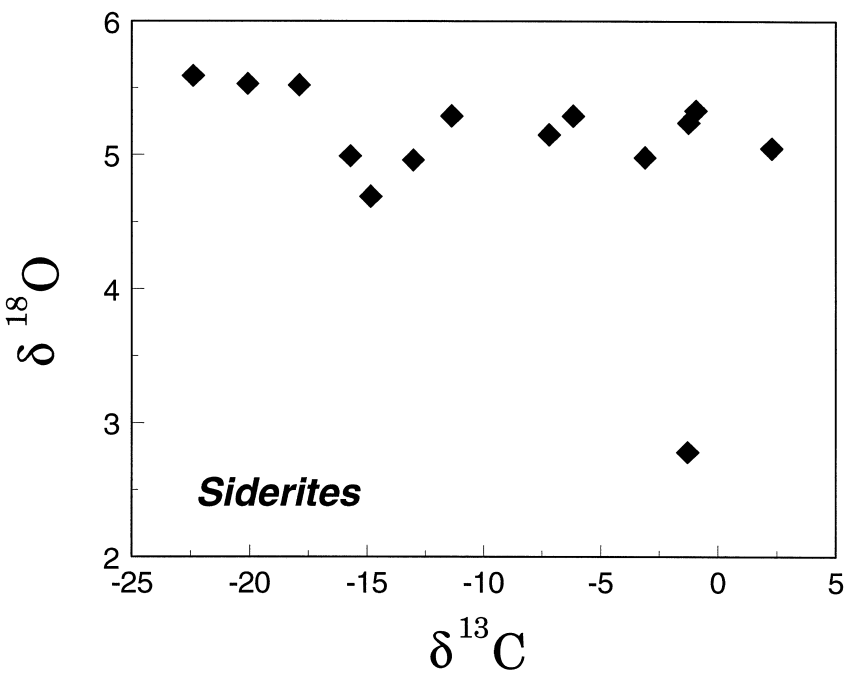

Figure 5. Cross-plot of carbon and oxygen isotope values for siderites.

These values record the carbon isotopic composition of the dissolved inorganic carbon (DIC), plus $\sim 10 \%$ o fractionation between DIC and solid carbonate (Emrich et al., 1970). The low carbon isotope values of DIC reflect the oxidation of carbon sources depleted in ${ }^{13} \mathrm{C}$, such as organic matter and methane (Claypool and Kaplan, 1974). In Amazon Fan sediments, the $\delta^{13} \mathrm{C}$ values of the DIC decrease from $10 \%$ near the surface to values as low as $-49 \%$ o at the base of the sulfate reduction zone and then increase again to near $0 \%$ by 10 to 20 mbsf (Burns and Shipboard Scientific Party, 1994; and unpubl. data). The precipitation of siderite is, therefore, probably presently restricted to the upper 10 to 20 mbsf.

The $\delta^{18} \mathrm{O}$ values of the siderites provide less of a constraint on the depth of precipitation, but are consistent with shallow formation. The $\delta^{18} \mathrm{O}$ values are mostly between $+4.5 \%$ and $+5.7 \%$ (Fig. 5 ), corresponding to temperatures of $2^{\circ}$ to $9^{\circ} \mathrm{C}$ (using the siderite-water temperature equation of Carothers et al., 1988, and using a $\delta^{18} \mathrm{O}_{\mathrm{H} 2 \mathrm{O}}=0.3$ standard mean ocean water; Burns and Maslin, 1995). Typical measured mudline temperatures were $\sim 2.5^{\circ} \mathrm{C}$ with geothermal gradients of $\sim 30$ to $40^{\circ} \mathrm{C} / \mathrm{km}$ (Flood, Piper, Klaus, et al., 1995). Consequently, $9^{\circ} \mathrm{C}$ is within the upper 250 to 300 mbsf. Overall, the pore-water chemistry suggests that all three diagenetic minerals can precipitate simultaneously in the zone of sulfate reduction and that vivianite and siderite are presently precipitating to depths of $\sim 10-20 \mathrm{mbsf}$. Precipitation of diagenetic iron minerals over this zone must indicate that sedimentary iron oxides are rapidly being reduced throughout this area and that iron oxide reduction is not restricted to a discrete zone above the sulfate reduction zone. Co-precipitation of iron minerals within the zone of sulfate reduction further suggests that the rate of iron oxide reduction must exceed the rate of sulfate reduction because excess iron is available beyond that precipitated by iron sulfides.

Berner (1971) suggested that the association of greigite, vivianite, and siderite indicated nonmarine sedimentation. This may often be true, but it is clearly not the case here. In most marine sediments, the rate of iron oxide reduction is far exceeded by the supply of sulfide through sulfate reduction, and all available dissolved iron can be precipitated as $\mathrm{FeS}_{2}$. In the Amazon Fan, however, the iron rich nature of sediments dictates that there is excess dissolved iron relative to dissolved sulfide, even within the sulfate reduction zone. The iron sulfides formed are therefore hydrotroilite and greigite, not pyrite; siderite and vivianite can also precipitate. An additional factor that probably favors vivianite precipitation over calcium-apatite, which is a much more common phosphate mineral in marine sediments, is the lack of detrital calcium carbonate. Calcium carbonate surfaces pro- 
mote apatite precipitation (deKanel and Morse, 1978), which is otherwise kinetically inhibited by the high dissolved magnesium concentration of seawater (Martens and Harriss, 1970).

\section{MODELED RATES OF REACTION Approach}

Early diagenesis may produce or utilize various dissolved species in sediment pore water. The resulting pore-water concentration gradients may be used to calculate fluxes into or out of the sediments and also to calculate rates for the various reactions influencing pore-water composition. A commonly made simplifying assumption is that a pore-water/sediment system is in steady state with respect to the sediment/water interface. In the Amazon Fan sediments, however, the very large change in the sedimentation rate that occurred at $\sim 10 \mathrm{ka}$ means that the system is unlikely to be in a steady state. The pore-water profiles are probably migrating relative to the sediment surface as a result of the change in sedimentation rate. A simple steady-state transport model therefore cannot be used to estimate reaction rates. For example, for sulfate, a qualitative assessment would suggest that the high sedimentation rates prior to $10 \mathrm{ka}$ effectively generate a high burial flux of sulfate into the sediments. When sedimentation rates drop at $10 \mathrm{ka}$, this flux disappears. For a constant rate of reaction, sulfate will be more rapidly removed from the pore fluids, and the concentration profile and depth to total sulfate depletion will migrate upward until the diffusive flux into the sediments increases enough to balance the removal of sulfate by bacterial sulfate reduction.

To quantitatively assess the reaction rates in this situation, several simplifying assumptions are required if the mathematics are not to become too intractable. The assumptions made are as follows:

1. Prior to $9.5 \mathrm{ka}$, the system had achieved a steady state.

2. The $100 \times$ decrease in sedimentation rates at $9.5 \mathrm{ka}$ is modeled as a complete cessation in sedimentation.

3. Porosity is constant with depth (no compaction).

4. The reaction rates remain constant with time for any particular depth below the seafloor.

5. Only simple linear adsorption is considered.

For the numerical models, a steady-state model incorporating diffusion, advection, and reaction is first applied to the system. This model is used to estimate the pre-Holocene, steady-state pore-water profile and rate of reaction. Then, a second, nonsteady-state model is applied to model the change in the pore-water concentrations since the sedimentation rate change. The second model uses the profile generated from the first model as an initial condition and uses the same reaction rate used in the first model. The second model is allowed to run for $9.5 \mathrm{ka}$, the period of time over which the Amazon Fan has received only pelagic sediment. The resulting pore-water profile is then compared with modern pore-water chemistry. By varying only the reaction rate (i.e., all other parameters are held constant), a unique reaction rate will be found that, when put through both models, will generate the modern pore-water profile. This reaction rate is relatively easily determined by iteration.

The steady-state diffusion-advection-reaction model solves the following general equation:

$$
\frac{d c}{d t}=0=D \frac{d^{2} c}{d z^{2}}-\omega \frac{d c}{d z}-J_{o} e^{-a z}
$$

where $D$ is the sediment diffusion coefficient corrected for porosity and ammonium, for adsorption as discussed below. $C$ is concentration, $z$ is depth, $\omega$ is the advective velocity (in this case the sedimen- tation rate), $J_{o}$ is the initial reaction rate, and $a$ is an exponential term that determines how rapidly the reaction rate decreases with depth.

Solving for $C(z)$ for boundary conditions of $C(z)=C_{o}$ at $x=0$, and $C(z)=C_{l}$ at $x=l$, where $l$ is any depth below which the concentrations are no longer changing and $C_{l}$ is the concentration at that depth, the particular solution is

$$
\begin{aligned}
& C(z)=C_{o}-\left(C_{l}-C_{o}\right) \frac{e^{\omega \frac{z}{D}}-1}{\omega \frac{l}{D}}+ \\
& \frac{J_{o}}{D a^{2}-\omega a}\left[\frac{e^{\omega \frac{z}{D}}-1}{e^{\omega \frac{l}{D}}-1}\left(1-e^{-a l}\right)+\left(e^{-a z}-1\right)\right] .
\end{aligned}
$$

The nonsteady-state model with diffusion and reaction but no advection solves the following general equation:

$$
\frac{d c}{d t}=D \frac{d^{2} c}{d z^{2}}-J_{o} e^{-a z}
$$

where the terms are as above with the addition that $t$ is time. The solution to this equation is taken from a similar heat flow problem given in Carslaw and Jaeger (1959, p. 79). The solution is

$$
\begin{aligned}
& C(z, t)=u+v z e^{x z}+\left(u-\frac{J_{o}^{\prime}}{D a^{2}}\right) \operatorname{erf} \frac{z}{2 \sqrt{D t}}+ \\
& \frac{J_{o}}{D a^{2}}\left[1-e^{-a z}+\frac{1}{2} e^{D t a^{2}-a z} \operatorname{erfc}\left(a \sqrt{D t}-\frac{z}{2 \sqrt{D t}}\right)-\right. \\
& \left.\frac{1}{2} e^{D t a^{2}+a z} \operatorname{erfc}\left(a \sqrt{D t}+\frac{z}{2 \sqrt{D t}}\right)\right]
\end{aligned}
$$

The equation has been modified to include an initial profile described by the terms $u$, the concentration at the surface, and $v$ and $x$, which control the shape of the initial profile with depth.

Although it is possible to apply the model to any of the dissolved species, only sulfate and ammonium were chosen for modeling. A large body of research has been done on sulfate reduction rates in a variety of marine environments. These results can be compared with those obtained here, allowing the Amazon Fan sediments to be put into a broader perspective.

In modeling ammonium production, an additional factor, adsorption, must be taken into account (Berner, 1976). Depending on sediment type, more than half of the ammonium produced during early diagenesis may be adsorbed onto the sediments or fixed into clay minerals (Berner, 1976; Rosenfeld, 1979). When applying the above equations to modeling pore-water ammonium concentrations, however, the equations need to be modified to include an ammonium adsorption coefficient, $K$ (see Berner [1976] and Rosenfeld [1979] for discussion). In Equation 2, the solution to the steady-state model, the $\omega$ term must be replaced by $\omega^{\prime}=\omega(1+K)$, and in Equation 4, the solution to the nonsteady-state model, $D$ must be replaced by $D^{\prime}=D /(1$ $+K)$ and $J_{o}$ is replaced by $J_{o}{ }^{\prime}=J_{o} /(1+K)$. For Long Island Sound sediments, which have similar high aluminosilicate contents to those of the Amazon Fan, Rosenfeld (1979) determined that $K$ was between 
1 and 2. A value of $K=1.5$ was thus used in the above equations when modeling ammonium.

\section{Results}

\section{Rates of Sulfate Reduction and Ammonium Production}

Model estimates of the rates of sulfate reduction and ammonium production for Sites 931, 939, and 944 are given in Table 1. Figures 6 and 7 show model results together with modern pore-water profiles for sulfate and ammonium respectively at Site 944 . For sulfate, the model results indeed show that the large decrease in sedimentation rate has led to a significant upward migration of the sulfate concentration gradient (Fig. 6). The estimated pre-Holocene steady-state profile yields a depth to total sulfate depletion of $\sim 35 \mathrm{~m}$, as compared with the value of $\sim 4 \mathrm{~m}$ in the modern sediments. The calculated preHolocene depth to complete sulfate depletion, however, should be viewed with some caution. Once the initial sulfate profile is such that the depth to sulfate depletion is greater than $\sim 30$ mbsf, the model is relatively insensitive to this initial gradient, because relatively large changes in the gradient cause small changes in the amount of sulfate in the pore-water reservoir available for sulfate reduction. For example, increasing the gradient so that sulfate goes to 0 at $30 \mathrm{vs.} 40 \mathrm{mbsf}$, only causes about a $10 \%$ change in the calculated sulfate reduction rate. The model is, however, quite sensitive to the $J_{o}$ term, with small variations causing significant differences in the final sulfate gradient.

The model can also be used to test whether the system has reached a new steady-state by inputting the calculated reaction rate to the nonsteady-state model for $t \rightarrow \infty$. In all cases, $t>9.5 \mathrm{ka}$ produced further migration of the pore-water sulfate profile to above the present location. Any estimate of sulfate reduction rates based solely on the modern profile would thus underestimate the rate if the Holocene sedimentation rates were used in the calculation, or greatly overestimate the sulfate reduction rate if the pre-Holocene sedimentation rates were used.

The model also shows that pore-water ammonium concentrations have increased significantly in the last $9.5 \mathrm{ka}$. For example, pre-Holocene ammonium concentrations are calculated to have reached a maximum of $\sim 4 \mathrm{mM}$ at $\sim 80 \mathrm{mbsf}$ at Site 944 , compared with a maximum of $\sim 8 \mathrm{mM}$ at $40 \mathrm{mbsf}$ for the modern sediments (Fig. 7). The ammonium pore-water profiles are also not currently at a steady state.

The calculated reaction rates are shown together with reaction rates for sediments from Long Island Sound and the Amazon shelf (Table 1). Long Island Sound sediments were used because they have sedimentation rates similar to Amazon Fan sediments, and there is a generally good correlation between sedimentation rates and both organic carbon burial rates and carbon oxidation rates for marine sediments (Müller and Suess, 1979; Henrichs and Reeburgh, 1987; Canfield, 1989; Ingall and Van Capellen, 1990). Table 1 shows that although sedimentation rates are similar, the rates of sulfate reduction and ammonium production are more than 2 orders of magnitude lower in the Amazon Fan than in Long Island Sound. Similarly, Berner (1978) found that Mississippi Delta sediments had anomalously low initial sulfate gradients (effectively a measure of the sulfate reduction rate) when compared with other marine sediments with similar sedimentation rates. In both cases, the low carbon remineralization rates seem to be caused by low reactivity of the organic matter in the system, which is probably related to the terrestrial origin of the organic matter.

Studies of organic matter remineralization on the Amazon shelf, however, suggest that physical factors associated with the environment of deposition can lead to high remineralization rates in spite of a dominantly terrestrial origin of the organic material (Aller et al., 1986; Aller and Blair, 1996). Modern Amazon shelf sediments are very similar in composition to glacial-aged Amazon Fan deposits, and in both settings metal-oxide reduction plays an important role in
Table 1. Diagenetic rates of reaction.

\begin{tabular}{lclc}
\hline \multicolumn{1}{c}{ Site } & $\begin{array}{c}\omega \\
(\mathrm{m} / \mathrm{ka})\end{array}$ & \multicolumn{1}{c}{$\begin{array}{c}J_{o} \mathrm{SO}_{4}^{-2} \\
\mathrm{M} / \mathrm{s}\end{array}$} & $\begin{array}{c}J_{o} \mathrm{NH}_{4}{ }^{+} \\
\mathrm{M} / \mathrm{s}\end{array}$ \\
\hline 931 & 3.6 & $2.5 \times 10^{-13}$ & $3.7 \times 10^{-14}$ \\
939 & 9 & $1.7 \times 10^{-13}$ & $2.5 \times 10^{-14}$ \\
944 & 11 & $6.0 \times 10^{-13}$ & $5.0 \times 10^{-14}$ \\
Amazon shelf & 30 & $6.8-9.8 \times 10^{-10}$ & \\
Long Island Sound & 3.0 & $6.3 \times 10^{-11}$ & $8.8 \times 10^{-12}$ \\
\hline
\end{tabular}

Notes: Amazon shelf data from Aller and Blair, 1996; Long Island Sound sulfate data from Goldhaber et al. (1977). Ammonium data from Rosenfeld, (1981).

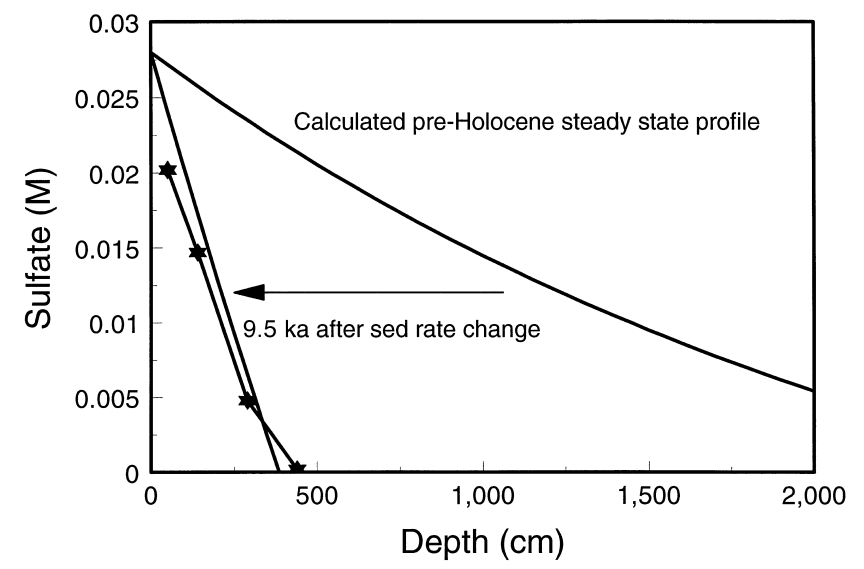

Figure 6. Model results for sulfate vs. depth for Site 944. Stars = pore-water data from Hole 944D. Values of constants used in model are $D=4 \times 10^{-6}$ $\mathrm{cm}^{2} / \mathrm{s}, a=0.001 \mathrm{~cm}^{-1}, u=0.028 \mathrm{M}, v=-1.6 \times 10^{-5} \mathrm{M} / \mathrm{cm}$, and $x=0.002$ $\mathrm{cm}^{-1}$. See text for details.

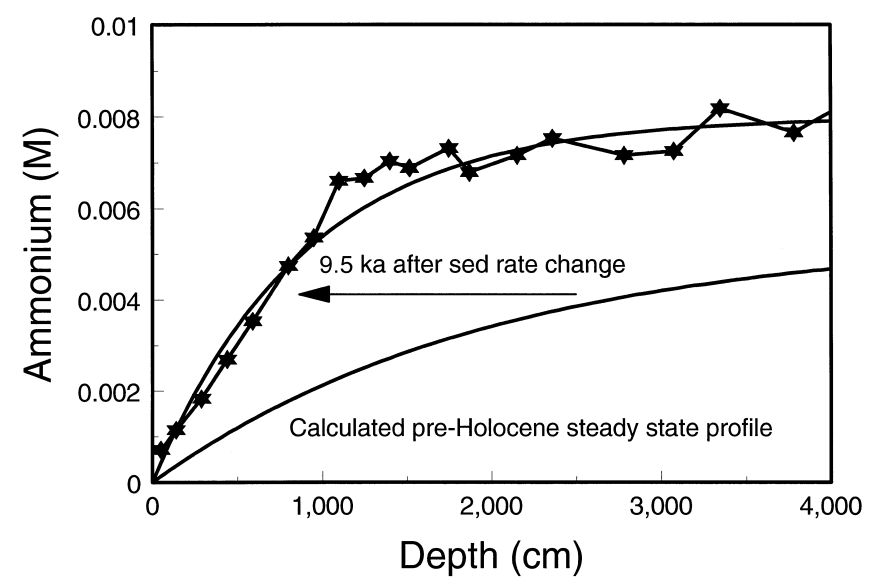

Figure 7. Model results for ammonium vs. depth for Site 944. Stars show pore-water data from Hole 944D. Values of constants used in model are $D=$ $8 \times 10^{-6} \mathrm{~cm}^{2} / \mathrm{s}, a=0.0003 \mathrm{~cm}^{-1}, u=0 \mathrm{M}, v=2 \times 10^{-6} \mathrm{M} / \mathrm{cm}$, and $x=0.0015$ $\mathrm{cm}^{-1}$.

early diagenesis (Aller et al., 1986; Mackin et al., 1988). Regardless of these similarities, sulfate reduction rates on the shelf are 2 to 3 orders of magnitude greater than those of the fan (Aller and Blair, 1996). This difference is mainly attributable to the frequent reworking of surficial Amazon shelf sediments, which results in very high "apparent sediment advection rates," $~ 900 \mathrm{~m} / \mathrm{k} . \mathrm{y}$. , much higher than 
the actual sedimentation rates of $\sim 30 \mathrm{~m} / \mathrm{k} . \mathrm{y}$. (Aller and Blair, 1996). The apparent sediment advection rates are 2 to 3 orders of magnitude greater than the advection rates (sedimentation rates) on the Amazon Fan (Table 1).

\section{Total Anoxic Carbon Remineralization}

The ammonium production rate can also be used to roughly estimate the overall anoxic rate of organic carbon remineralization since all the anoxic carbon remineralization reactions produce ammonium (Froelich et al., 1979). Using ammonium production in this manner can lead to overestimation of the overall anoxic remineralization rate (Berner, 1980) if, as observed in some environments, the more nitrogen-rich organic compounds are preferentially being metabolized. The Amazon Fan, however, probably represents the best case for such an estimation. The organic material reaching the fan is almost entirely of terrestrial origin, is uniform in composition, and is apparently fairly "weathered" by the time it reaches the sea (Hedges et al., 1986; Goñi, this volume). As a result, there is neither a mixture of carbon sources nor a highly labile fraction of marine origin. More importantly, there is no measurable change in the $\mathrm{C}: \mathrm{N}$ ratio of the sediments over the depth range of the calculation, or even over several hundreds of mbsf. The relatively constant $\mathrm{C}: \mathrm{N}$ ratios, however, may partly be a result of the relatively low overall rates of organic carbon oxidation and the low percentage of the total organic carbon (TOC) remineralized over the upper $100 \mathrm{~m}$ (see below). Still, modeling the ammonium production will give a rough estimate of the overall anoxic carbon remineralization and will be useful for comparison to other areas.

For this calculation, the initial reaction rate, $J_{o}$, must be integrated over the depth range for which it is significantly large. The latter is effectively the depth range over which the pore-water concentration is changing, or from $z=0$ to $10,000 \mathrm{~cm}$ :

$$
\int_{0}^{10000} J_{o} e^{-a z}=\left.\frac{J_{o} e^{-a z}}{-a}\right|_{0} ^{10000} \approx \frac{J_{o}}{a} .
$$

Using Site 944 as an example, this formula yields an integrated rate of ammonium production of $1.67 \times 10^{-10} \mathrm{M} / \mathrm{s} / \mathrm{cm}$ or $5.26 \times 10^{-6} \mathrm{~mol} /$ $\mathrm{cm}^{2} / \mathrm{yr}$. If this rate is multiplied by the average $\mathrm{C} / \mathrm{N}$ of the sediments, $\sim 8$ (Shipboard Scientific Party, 1995), then the TOC remineralization rate at Site 944 is $4.2 \times 10^{-5}$ moles $\mathrm{C} / \mathrm{cm}^{2} / \mathrm{yr}$. Similarly, the rate for Site 939 would be $2.1 \times 10^{-5}$ moles $\mathrm{C} / \mathrm{cm}^{2} / \mathrm{yr}$.

The anoxic carbon remineralization rate can be used to calculate the TOC remineralized in the sediments during burial. The sedimentation rate for Site 944 is $\sim 11 \mathrm{~m} / \mathrm{k} . \mathrm{y}$. for the sediments older than 9.5 $\mathrm{ka}$, giving an age of the sediment at $100 \mathrm{mbsf}$ of $\sim 18.5 \mathrm{ka}$ (Holocene sediments $=9.5 \mathrm{ka}$ ). Multiplying times the rate yields a total of 0.77 moles $\mathrm{C} / \mathrm{cm}^{2}$, or $9.2 \mathrm{~g} \mathrm{C} / \mathrm{cm}^{2}$ remineralized. The same $100 \mathrm{~m} \times 1 \mathrm{~cm}^{2}$ column of sediment contains $\sim 234 \mathrm{~g} \mathrm{C}$ (using a sediment density of $2.6 \mathrm{~g} / \mathrm{cm}^{3}$ and an organic carbon content of $0.09 \%$; Shipboard Scientific Party, 1995). A maximum of $3.9 \%$ of the organic carbon in the sediments thus has been remineralized by anoxic processes.

\section{Implications for Diagenetic Mineral Formation}

The calculated pre-Holocene sulfate profiles show that the depth to total sulfate depletion was probably on the order of several tens of meters, rather than the present several meters. Profiles of other dissolved species, such as phosphate, alkalinity, calcium, and magnesium, are related to the sulfate reduction zone, and it is therefore logical to assume that the pore-water profiles of these ions also were also less steep pre-Holocene. Furthermore, the range over which the di- agenetic minerals formed was likely to have been much greater in the pre-Holocene than at present. For example, if the pre-Holocene sulfate reduction zone at Site 944 extended to $\sim 40$ mbsf, then iron sulfide minerals could have formed to that depth, and siderite and vivianite may have formed as deep as 60-80 mbsf.

\section{CONCLUSIONS}

1. The high sedimentation rates and high iron contents of Amazon Fan sediments result in the assemblage of early diagenetic minerals such as iron sulfides (hydrotroilite and greigite), vivianite, and siderite.

2. Core descriptions, pore-water analyses, and EDS analyses of vivianite and siderite indicate that all three diagenetic minerals are presently forming within the zone of sulfate reduction (5$10 \mathrm{mbsf}$ ). Vivianite and siderite continue to form in the 5-10 $\mathrm{m}$ below the zone of sulfate reduction.

3. Numerical modeling demonstrates that the present pore-water profiles are not in a steady state and have migrated through the sediments in response to the large reduction in sedimentation rates that occurred at $\sim 9.5 \mathrm{ka}$. Calculated initial rates of sulfate reduction and ammonium formation range from 1.7 to $6.0 \times$ $10^{-13} \mathrm{M} / \mathrm{s}$ and 2.5 to $5.0 \times 10^{-14} \mathrm{M} / \mathrm{s}$, respectively. These rates are more than 2 orders of magnitude lower than near-shore sediments deposited at similar sedimentation rates.

4. The total rate of anoxic carbon remineralization is roughly $2-4$ $\times 10^{-5}$ moles $\mathrm{C} / \mathrm{cm}^{2} / \mathrm{yr}$.

5. The pre-Holocene depths to sulfate depletion were on the order of 20-50 mbsf, rather than the 5-10 mbsf observed at present. Thus, the zones of diagenetic mineral formation were likely also considerably deeper than indicated by present porewater chemistry.

\section{ACKNOWLEDGMENTS}

I am grateful to Karl Ramseyer for help with SEM and EDS analyses, and to Urs Mader for assistance with the numerical modeling. Helpful reviews were provided by R. Aller and J. Compton. My participation on Leg 155 was partially supported by the Schweizerischer Nationalfonds zur Förderung der wissenschaftlichen Forschung.

\section{REFERENCES}

Aller, R.C., and Blair, N.E., 1996. Sulfur diagenesis and burial on the Amazon shelf: major control by physical sedimentation processes. Geo-Mar. Lett., 16:3-10.

Aller, R.C., Mackin, J.E., and Cox, R.T., 1986. Diagenesis of Fe and S in Amzon inner shelf muds: apparent dominance of Fe reduction and implications for the genesis of ironstones. Cont. Shelf Res., 6:263-289.

Berner R.A., 1971. Principles of Chemical Sedimentology: New York (McGraw-Hill).

1974. Kinetic models for the early diagenesis of nitrogen, sulfur, phosphorous, and silicon in anoxic marine sediments. In Goldberg, E.D. (Ed.), The Sea (Vol. 5): New York (Wiley), 427-450.

1976. Inclusion of adsorption in the modeling of early diagenesis. Earth Planet. Sci. Lett., 29:333-340.

, 1978. Sulfate reduction and the rate of deposition of marine sediments. Earth Planet. Sci. Lett., 37:492-498.

, 1980. Early Diagenesis: A Theoretical Approach: New Jersey (Princeton Univ. Pr.).

Burns, S.J., and the Shipboard Scientific Party, 1994. Pore-water geochemistry and early diagenesis of Amazon Fan sediments, Leg 155 ODP. Eos, 75:317.

Burns, S.J., and Maslin, M., 1995. $\delta^{18} \mathrm{O}$ values of glacial seawater estimated from sediment pore-waters, Amazon Fan, Leg 155 ODP. Eos, 76:296. 
Canfield, D.E., 1989. Sulfate reduction and oxic respiration in marine sediments: implications for organic carbon preservation in euxinic environments. Deep-Sea Res. Part A, 36:121-138.

Carothers, W.W., Adami, L.H., and Rosenbauer, R.J., 1988. Experimental oxygen isotope fractionation between siderite-water and phosphoric acidliberated $\mathrm{CO}_{2}$-siderite. Geochim. Cosmochim. Acta, 52:2445-2450.

Carslaw, H.S., and Jaeger, J.C., 1959. Conduction of Heat in Solids (2nd ed.): Oxford (Clarendon).

Claypool, G.E., and Kaplan, I.R., 1974. The origin and distribution of methane in marine sediments. In Kaplan, I.R. (Ed.), Natural Gases in Marine Sediments: New York (Plenum), 99-139.

Damuth, J.E., 1977. Late Quaternary sedimentation in the western equatorial Atlantic. Geol. Soc. Am. Bull., 88:695-710.

Damuth, J.E., and Fairbridge, R.W., 1970. Equatorial Atlantic deep-sea arkosic sands and ice-age aridity in tropical South America. Geol. Soc. Am. Bull., 81:189-206.

Damuth, J.E., and Flood, R.D., 1984. Morphology, sedimentation processes, and growth pattern on the Amazon deep-sea fan. Geo-Mar. Lett., 3:109117.

Damuth, J.E., Flood, R.D., Knowsmann, R.O., Belderson, R.H., Gorini, M.A., 1988. Anatomy and growth patterns of Amazon deep-sea fan as revealed by long-range side-scan sonar (GLORIA) and high-resolution seismic studies. AAPG Bull., 72:885:911.

Damuth, J.E., and Kumar, N., 1975. Amazon Cone: morphology, sediments, age, and growth pattern. Geol. Soc. Am. Bull., 86:863-878.

deKanel, J., and Morse, J.W., 1978. The chemistry of orthophosphate uptake from seawater onto calcite and aragonite. Geochim. Cosmochim. Acta, 42:1335-1340.

Emrich, K., Ehhalt, D.H., and Vogel, J.C., 1970. Carbon isotope fractionation during the precipitation of calcium carbonate. Earth and Planet. Sci. Lett., 8:363-371.

Ericson, D.B., Ewing, M., Wollin, G., and Heezen, B.C., 1961. Atlantic deepsea sediment cores. Geol. Soc. Am. Bull., 72:193-286.

Flood, R.D., Piper, D.J.W., Klaus, A., et al., 1995. Proc. ODP, Init. Repts., 155: College Station, TX (Ocean Drilling Program).

Froelich, P.N., Klinkhammer, G.P., Bender, M.L., Luedtke, N.A., Heath, G.R., Cullen, D., Dauphin, P., Hammond, D., Hartmann, B., and Maynard, V, . 1979. Early oxidation of organic matter in pelagic sediments of the eastern equatorial Atlantic: suboxic diagenesis. Geochim. Cosmochim. Acta, 43:1075-1090.

Goldhaber, M.B., Aller, R.C., Cochran, J.K., Rosenfeld, J.K., Martens, C.S., and Berner, R.A., 1977. Sulfate reduction, diffusion, and bioturbation in
Long Island Sound sediments: report of the FOAM group. Amer. J. Sci., 277:193-237.

Hedges, J.I., Clark, W.A., Quay, P.D., Rochey, J.E., Devol, A.H., and Sandos, U.M., 1986. Composition and fluxes of particulate organic material in the Amazon River. Limnol. Oceanogr., 31:717-738.

Henrichs, S.M., and Reeburgh, W.S., 1987. Anaerobic mineralization of marine sediment organic matter: rates and the role of anaerobic processes in the oceanic carbon economy. J. Geomicrobiol., 5:191-237.

Ingall, E.D., and Van Capellen, P., 1990. Relation between sedimentation rate and burial of organic phosphorous and organic carbon in marine sediments. Geochim. Cosmochim. Acta, 54:373-386.

Mackin, J.E., Aller, R.C., and Ullman, W.J., 1988. The effects of iron reduction and non-steady-state diagenesis on iodine, ammonium, and boron distributions in sediments from the Amazon continental shelf. Cont. Shelf Res., 8:363-386.

Manley, P.L., and Flood, R.D., 1988. Cyclic sediment deposition within the Amazon deep-sea fan. AAPG Bull., 72:912-925.

Martens, C.S., and Harriss, R.C., 1970. Inhibition of apatite precipitation in the marine environment by magnesium ions. Geochim. Cosmochim. Acta, 34:621-625.

Müller, P.J., and Suess, E., 1979. Productivity, sedimentation rate, and sedimentary organic matter in the oceans, I. Organic carbon preservation. Deep-Sea Res. Part A, 26:1347-1362.

Nittrouer, C.A., Kuehl, S.A., DeMaster, D.J., and Kowsman, R.O., 1986. The deltaic nature of Amazon shelf sedimentation. Geol. Soc. Am. Bull., 97:444-458.

Rosenfeld, J.K., 1979. Ammonium adsorption in nearshore anoxic sediments. Limnol. Oceanogr., 24:356-364.

, 1981. Nitrogen diagenesis in Long Island Sound sediments. Am. J. Sci., 281:436-462.

Shipboard Scientific Party, 1995. Site 944. In Flood, R.D., Piper, D.J.W., Klaus, A., et al., 1995. Proc. ODP, Init. Repts., 155: College Station, TX (Ocean Drilling Program), 591-633.

Showers, W.J., and Bevis, M., 1988. Amazon Cone isotopic stratigraphy: evidence for the source of the tropical meltwater spike. Peleogeogr., Paleoclimatol., Paleoecol., 64:189-199.

Date of initial receipt: 5 December 1995

Date of acceptance: 13 June 1996

Ms 155SR-236 